Review Article

\title{
ADP-ribosylation: from molecular mechanisms to human disease
}

\author{
Nicolas C. Hoch ${ }^{1}$ iD and Luis M. Polo ${ }^{2,3}$ (ID \\ ${ }^{1}$ Departamento de Bioquímica, Instituto de Química, Universidade de São Paulo, São Paulo, SP, Brazil. \\ ${ }^{2}$ Cancer Research UK DNA Repair Enzymes Group, Genome Damage and Stability Centre, School of Life \\ Sciences, University of Sussex, Falmer, Brighton, UK. \\ ${ }^{3}$ Institute of Histology and Embryology of Mendoza - CONICET, Mendoza, Argentina.
}

\begin{abstract}
Post-translational modification of proteins by ADP-ribosylation, catalysed by poly (ADP-ribose) polymerases (PARPs) using NAD as a substrate, plays central roles in DNA damage signalling and repair, modulates a range of cellular signalling cascades and initiates programmed cell death by parthanatos. Here, we present mechanistic aspects of ADP-ribose modification, PARP activation and the cellular functions of ADP-ribose signalling, and discuss how this knowledge is uncovering therapeutic avenues for the treatment of increasingly prevalent human diseases such as cancer, ischaemic damage and neurodegeneration.
\end{abstract}

Keywords: ADP ribose, PARP, DNA damage response, DNA repair, parthanatos.

Received: March 14, 2019; Accepted: July 4, 2019.

\section{PARP members, structure and activity}

ADP-ribosyl transferases, also known as poly(ADPribose) polymerases (PARPs), are specific enzymes that transfer the ADP-ribose moiety from $\beta$-nicotinamide adenine dinucleotide $\left(\mathrm{NAD}^{+}\right)$to a target macromolecule, mainly proteins. This activity was identified in the 1960 s (Chambon et al., 1963), and almost 20 years later, singleand double-strand DNA breaks were determined as enzyme activators in cell extracts (Benjamin and Gill, 1980a; 1980b). Since then, ADP-ribosylation of proteins has been recognized as a central posttranslational modification in a range of cellular processes, such as DNA damage signalling and repair, transcription, Wnt signalling and programmed cell death (Gibson and Kraus, 2012; Virag, 2013; DaRosa et al., 2015; Kraus, 2015).

ADP-ribosylation can occur either as a single mono(ADP-ribose) unit (MAR) or as poly(ADP-ribose) (PAR) chains, which can be linear or branched. Since the ADP-ribosyl (ADPr) group contains a high density of negative charges, the addition of ADPr units can dramatically change the biophysical properties of a target protein or promote protein-protein interactions (Figure 1). For example, long PAR chains have been proposed to produce a halo of

Send correspondence to Nicolas Carlos Hoch. Department of Biochemistry, Institute of Chemistry, University of São Paulo, Av. Prof. Lineu Prestes 748, 05508-000 São Paulo, SP, Brazil. E-mail: nicolas@iq.usp.br or to Luis Mariano Polo. Instituto de Histología y Embriología de Mendoza (IHEM, CONICET), Facultad de Ciencias Médicas, Universidad Nacional de Cuyo, Casilla de correo 56 Mendoza - Argentina. CP 5500. E-mail: marianopolo@gmail.com negatively charged density around the target protein, disrupting the liquid phase in which the protein is embedded (Altmeyer et al., 2015).

There are 17 known members of the PARP family in the human genome (Barkauskaite et al., 2015), and most of these possess the ability to auto-modify, often on multiple sites (Vyas et al., 2014). However, only a few are bona fide poly(ADP-ribose) polymerases, while most are in fact mono(ADP-ribosyl) transferases (Vyas et al., 2014). In human cells, the majority of PARP activity is exerted by PARP1 (85\%-90\%) and by PARP2 (10\%-15\%) (Szanto et al., 2012).

PARPs are multidomain proteins that contain a common structurally related catalytic domain that is also found in a range of pathogenic toxins from both gram-positive and gram-negative bacteria such as Bacillus sphaericus, Clostridium sp., Corynebacterium diphteriae, Salmonella enterica, Vibrio cholera and Escherichia coli, (Laing et al., 2011; Karlberg et al., 2013; Simon et al., 2014; Barkauskaite et al., 2015; Langelier et al., 2018). The catalytic domains of 5 of the 17 human members - PARP1, 2, 3, 4 and 16 -, contain an additional subdomain known as helical domain (HD), which has autoinhibitory functions by sterically hindering NAD+ binding and has to be removed for every catalytic cycle (Dawicki-McKenna et al., 2015; Langelier et al., 2018).

\section{Reaction mechanism}

The PARP1 active site is formed between the catalytic domain (ART domain) and the helical domain (HD) 

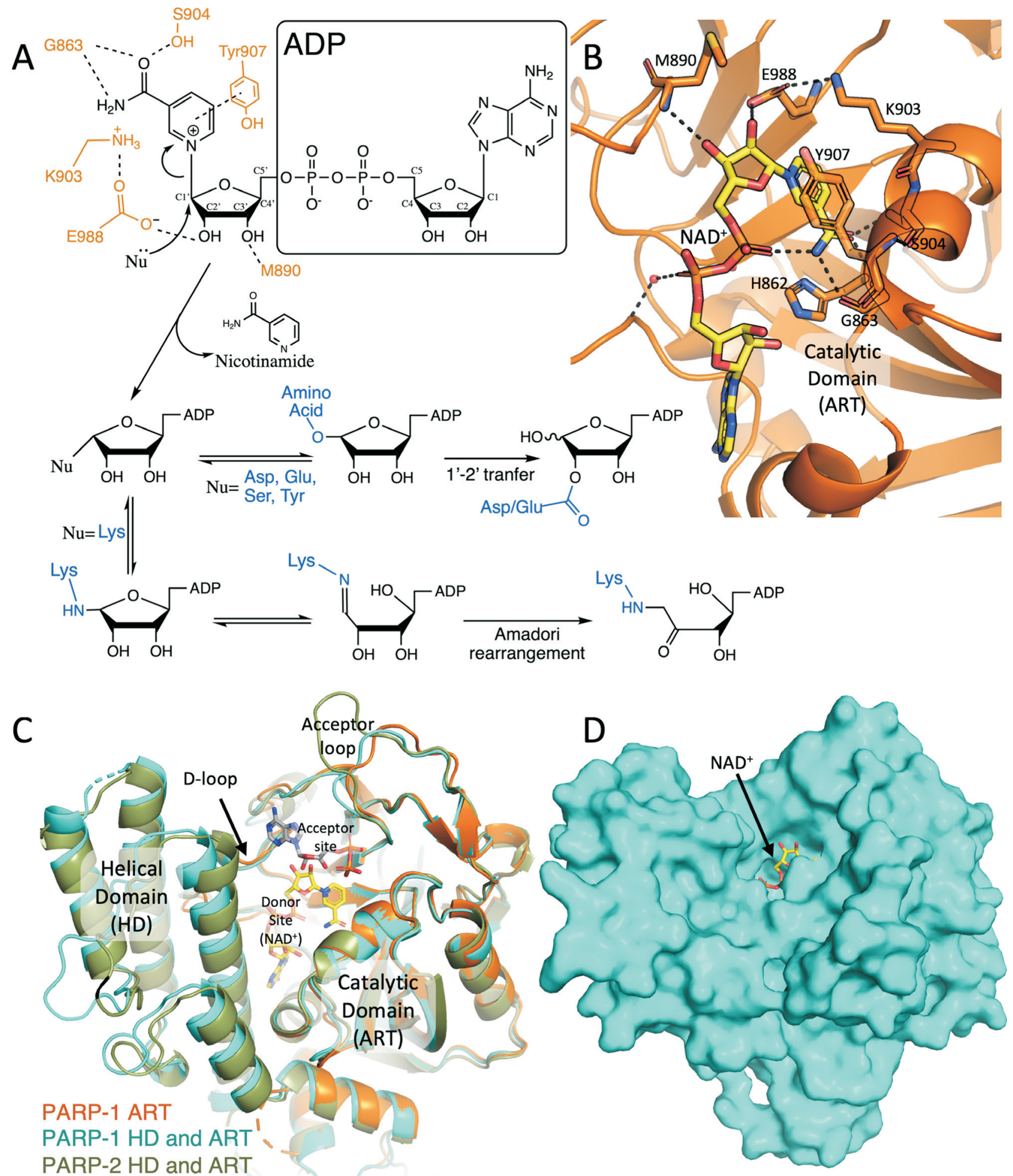

Figure 1 - Schematic mechanism of ADP ribosylation reaction and the catalytic domain of DNA-dependant PARPs. A) A simplified overview of the (ADP)-ribosylation reactions catalysed by PARPs. The final products depend on the acceptor residue acting as a nucleophile (Nu, in blue). PARP1 active-site residues interacting with the ribose-nicotinamide moiety of NAD ${ }^{+}$are illustrated in orange. B) The NAD ${ }^{+}$(modelled based on the human PARP1 bound to benzamide adenine dinucleotide [PDB: 6BHV], carbon atoms in yellow) in an extended conformation, bound to the catalytic domain of human PARP1 (ART in cartoon, orange, [PDB: 6BHV]). The residues involved in the catalysis are presented as sticks. C) Superposed cartoon view of human PARP-1 ART domain (orange, [PDB: 6BHV]), PARP1 (light blue, [PDB: 5WS1]) and PARP2 (green, [PDB: 3KJD]) showing the structure of the entire catalytic domains (ART and HD). The modelled NAD ${ }^{+}$(in yellow) denotes the donor site, while a molecule of ADP (modelled by superimposing the structures of chicken PARP1 [PDB: 1A26] to the human PARP1 [PDB: 3KJD]) indicates the acceptor site. Donor loop (D-loop) and acceptor loop are labelled. D) Surface representation of human PARP1 [PDB: 3KJD] with NAD ${ }^{+}$modelled into the active site. The ribose group to be attacked is exposed to the solvent. 
(Figure 1B, C). The substrate to be PARylated binds to the acceptor site on the surface of the ART domain, defined by the acceptor loop (residues 977 to 988 in PARP1) that is also thought to regulate polymer length and chain branching (Vyas et al., 2014; Chen et al., 2018). NAD ${ }^{+}$binds to the donor site in an extended conformation, such that the ADP-ribose moiety interacts with the D-loop in the ART domain (residues 875 to 894 in PARP1) (Gibson and Kraus, 2017), while the nicotinamide moiety forms three hydrogen bonds with Gly863, Ser904 and Tyr907 (PARP1 numbering) (Figure 1B, C) (Langelier et al., 2018).

Two reaction mechanisms have been proposed, with detailed structural evidence supporting the second mechanism (Tsurumura et al., 2013). One is an $\mathrm{S}_{\mathrm{N}} 2$ displacement mechanism, with the formation of a penta-coordinated transition state (Marsischky et al., 1995), while the other is an $\mathrm{S}_{\mathrm{N}} 1$ strain-alleviation mechanism that involves the formation of a stable furanosyl oxocarbenium ion (van Rijssel et $a l ., 2014)$, and a rotation around the phosphodiester bond (Simon et al., 2014; Cohen and Chang, 2018). In either case, the nucleophilic attack is performed by an oxygen or a nitrogen atom from the side chain of the target amino acid, which can be glutamic acid, aspartic acid, serine, cysteine, arginine, lysine or tyrosine (Ogata et al., 1980; Altmeyer et al., 2009; Laing et al., 2011; Rosenthal and Hottiger, 2014; Bonfiglio et al., 2017; Leslie Pedrioli et al., 2018). Subsequently, the product can have chemical reorganisations: glutamate and aspartate modifications undergo a $\mathrm{C} 1$ ' $-\mathrm{C} 2$ ' transfer, and lysine linkages suffer an Amadori rearrangement to form a stable ketoamine (Altmeyer et al., 2009; Morgan and Cohen, 2015; Cohen and Chang, 2018) (Figure 1A). Ultimately, nicotinamide is released as a by-product. Linear PAR chains are formed using the hydroxyl group in $\mathrm{C} 2$ of the ADP-ribose moiety, and branching involves the oxygen in C2' for the nucleophilic attack (Juarez-Salinas et al., 1982; Chen et al., 2018).

Recently, an important modifier of PARP catalytic activity, termed histone PARylation factor (HPF1), was described (Gibbs-Seymour et al., 2016). HPF1 is responsible for switching specificity of PARP1/2 towards serine and tyrosine residues and from auto-PARylation to PARylation of chromatin components and remodellers (Bonfiglio et al., 2017; Leslie Pedrioli et al., 2018). HPF1 also seems to modulate the length of ADPr polymers and can itself be mono(ADP)ribosylated by PARP1 (Leslie Pedrioli et al., 2018). Recent studies revealed that serine could be the predominant PARylation site at chromatin after DNA damage (Leidecker et al., 2016; Palazzo et al., 2018). Strikingly, some results indicate that despite the presence of a hydroxyl group and the resemblance with serine, threonine is not modified by PARP in mammalian cells (Leslie Pedrioli et al., 2018).

\section{Domain architecture and activation}

In addition to the catalytic domain, PARPs contain different domains that mediate protein-protein or protein- nucleic acid interactions, such as ankyrin repeats (PARP5a and 5b, called tankyrases); $\mathrm{CCCH}$ zinc fingers (PARP7, 12 and 13), and macrodomains (PARP9, 14 and 15) (Gibson and Kraus, 2012; Karlberg et al., 2013; Barkauskaite et al., 2015). The DNA-dependent PARPs 1, 2 and 3 have DNA binding domains that promote their activation by DNA breaks. These proteins contain a WGR (Trp-Gly-Arg) domain, which upon DNA binding promotes conformational changes in the HD that activate the catalytic domain (Eustermann et al., 2015; Grundy et al., 2016; Obaji et al., 2018).

In PARP1, the WGR domain is not involved in the initial recognition and binding of DNA-breaks (Eustermann et al., 2015). Instead, three zinc fingers (ZnFs) make the primary contact with the DNA. The first two ZnFs at the PARP1 N-terminus are necessary and sufficient for protein recruitment to DNA-damage sites in vivo, using structurally equivalent residues (Ali et al., 2012). Recent NMR studies suggest that $\mathrm{ZnF} 2$ is the leading domain that binds to the 3' end of the break, followed by $\mathrm{ZnF} 1$, which recognises the 5' end. This complex promotes $\mathrm{ZnF} 3$ recruitment, which leads to WGR domain binding to a surface formed by ZnF1, ZnF3 and DNA (Eustermann et al., 2015). Interestingly, PARP1 makes much more extensive contacts with the DNA surrounding the break than at the break site per se, allowing for the recognition of DNA breaks from a variety of sources. In contrast, the WGR domains of both PARP2 and PARP3 (which do not have $\mathrm{ZnFs}$ ) play a key role in DNA binding and discriminate between different DNA ends by recognising the presence of a 5 'phosphate group at the DNA break site (Langelier et al., 2014; Grundy et al., 2016; Obaji et al., 2018).

In addition to the domains involved in DNA-break recognition and catalytic activation, PARP1 contains a BRCT-like (BRCA1 C-terminus) domain where most of the auto-modification sites have been identified (Altmeyer et al., 2009; Tao et al., 2009) and which is implicated in mediating protein-protein interactions (Liu et al., 2011; Noren Hooten et al., 2011; Hsu et al., 2019)

\section{ADP-ribosylation of DNA}

ADP-ribosylation was long considered a protein modification exclusively. However, recent reports have independently shown that DNA-dependent PARPs can add ADPr covalently to DNA ends, at least in vitro (Talhaoui et al., 2016; Munnur and Ahel, 2017; Zarkovic et al., 2018).

PARP1, PARP2 and PARP3 all modify both 3' or 5' terminal phosphate groups via a phosphodiester bond, and PARP1 and PARP2 can also modify free 3'hydroxyl groups to generate a ribose-ribose bond (Talhaoui et al., 2016; Munnur and Ahel, 2017; Zarkovic et al., 2018). Modification of 5' phosphorylated ends may protect them from phosphatase activity, offering a possible function for this modification in vivo. Surprisingly, ADP-ribosylation of single-stranded DNA gaps promoted their ligation by 
DNA ligases even in the absence of ATP, suggesting that DNA modification "activates" these ends for ligation (Belousova et al., 2018). However, it is currently unclear if and how this promotes DNA repair in vivo.

\section{Cellular Functions of ADP-ribosylation}

\section{DNA damage signalling and repair}

Perhaps the best-studied cellular role of ADP-ribosylation is the crucial function of PARP1 and PARP2 in promoting the repair of DNA strand breaks (Ray Chaudhuri and Nussenzweig, 2017). PARP1 is a sensor of DNA breaks with high affinity for DNA and a lesion recognition mechanism that allows it to be activated by DNA breaks induced by a broad range of sources (Eustermann et al., 2015).

PARP1 activation leads to extensive HPF1-assisted PARylation of chromatin components surrounding DNA damage sites (Boulikas, 1988; Gibbs-Seymour et al., 2016). PARylation of histone $H 1$ and all four nucleosomal histones, as well as HMG proteins, occurs on a number of modification sites, predominantly serines (Bonfiglio et al., 2017; Palazzo et al., 2018), but whether these have differing functions or are simply a chromatin attachment site for PAR chains is currently unclear. In addition to changes in the chromatin environment (discussed below), PARylation leads to the recruitment of a myriad of DNA repair factors, which often contain dedicated PAR-binding domains such as BRCT, PBZ, WWE and macrodomain, or a short positively charged peptide sequence termed the PAR-binding motif (PBM) (Beck et al., 2014a). Crucially, PARP1 automodification reduces its affinity for DNA, allowing the repair machinery to access the damage site (Satoh and Lindahl, 1992).

In the case of DNA single-strand break repair (SSBR), PARP1 and PARP2-dependent ADP-ribosylation leads to the recruitment of the central scaffolding protein XRCC1, which contains a PAR-binding BRCT domain (Caldecott, 2008; Breslin et al., 2015; Polo et al., 2019). Lesions repaired by this pathway arise predominantly from oxidative damage to the DNA, but are also formed as intermediates of the base excision repair pathway or by the abortive activity of topoisomerases and DNA ligases (Caldecott, 2014). XRCC1 interacts with DNA and a range of DNA modifying enzymes that process these lesions to restore canonical 3' $\mathrm{OH}$ and 5'P termini required for subsequent re-ligation of the damaged strand by DNA ligase III (Caldecott, 2008; Polo et al., 2019) (Figure 2A).

In cycling cells, this pathway prevents the collision of unrepaired single-strand breaks (SSBs) with the DNA replication machinery, which would convert SSBs into much more deleterious DNA double-strand breaks (DSBs) (Figure 2B). As these DNA replication-induced DSBs are oneended, their accurate repair requires homologous recombination using the sister chromatid (Saleh-Gohari et al.,
2005; Cortes-Ledesma and Aguilera, 2006). This leads to a distinctive requirement for functional homologous recombination in cells with defective single-strand break repair, as discussed in the context of PARP inhibitors below. Interestingly, SSBR was recently shown to serve as a backup mechanism for the "repair" of unligated Okazaki fragments during DNA replication (Hanzlikova et al., 2018) and is also thought to play a role in a sub-pathway of DNA double-strand break repair termed microhomology-mediated end-joining (Sfeir and Symington, 2015).

PARP1 also plays a crucial role in promoting the reversal of dysfunctional DNA replication forks (Ray Chaudhuri et al., 2012; Ray Chaudhuri and Nussenzweig, 2017). Fork reversal is an active process that occurs when DNA replication stalls due to impediments to the progression of the replisome (Zellweger et al., 2015) and involves the formation of a "chicken foot" structure in which the newly synthesised daughter strands anneal to each other (Quinet et al., 2017) (Figure 2C). The molecular mechanisms of this process are currently under intense investigation, but PARP1 seems to stabilise reversed forks by preventing the helicase RECQ1 from dismantling the reversed DNA arm (Berti et al., 2013).

PARP1 engagement of DNA breaks, particularly DSBs, has to be carefully coordinated with other endbinding proteins to ensure genomic stability. The $\mathrm{Ku} 70 / \mathrm{Ku} 80$ heterodimer is a sensor of DSBs for repair by the non-homologous end-joining pathway (NHEJ) (Shibata et al., 2018). PARP1 is thought to compete with $\mathrm{Ku}$ for DSB binding so that PARP1 loss allows Ku to engage DNA ends aberrantly and vice-versa, leading to damage hypersensitivity and genomic instability (Hochegger et al., 2006; Cheng et al., 2011). This is highlighted by a recent report suggesting that PARP1 may participate in the eviction of $\mathrm{Ku}$ from breaks that are destined for repair by NHEJindependent pathways (Yang et al., 2018). Conversely, the Mre11/Rad50/Nbs1 (MRN) complex, which also plays a very early role in the signalling and repair of DSBs, has been suggested to require PARP1 for its recruitment to break sites (Haince et al., 2008; Bryant et al., 2009). However, there are also instances in which PARP1 activation must be actively suppressed, such as at telomeres, where the shelterin complex, and in particular TRF2, prevents PARP1 binding to avoid attempts of "repairing" telomeric DNA ends (Schmutz et al., 2017).

PARP1 and PARP2 are partially redundant, as illustrated by the early embryonic lethality of the double knockout mouse (Menissier de Murcia et al., 2003). Phenotypically, PARP2 can replace PARP1 for many of the roles described above, but is restricted in part by a more limited specificity for DNA breaks with 5'P ends (Langelier et al., 2014). Both enzymes are redundant for XRCC1 recruitment to oxidative lesions (Hanzlikova et al., 2017) and the repair of DNA base damage (Ronson et al., 2018), but only PARP1 seems to generate ADP-ribose in response to topoi- 

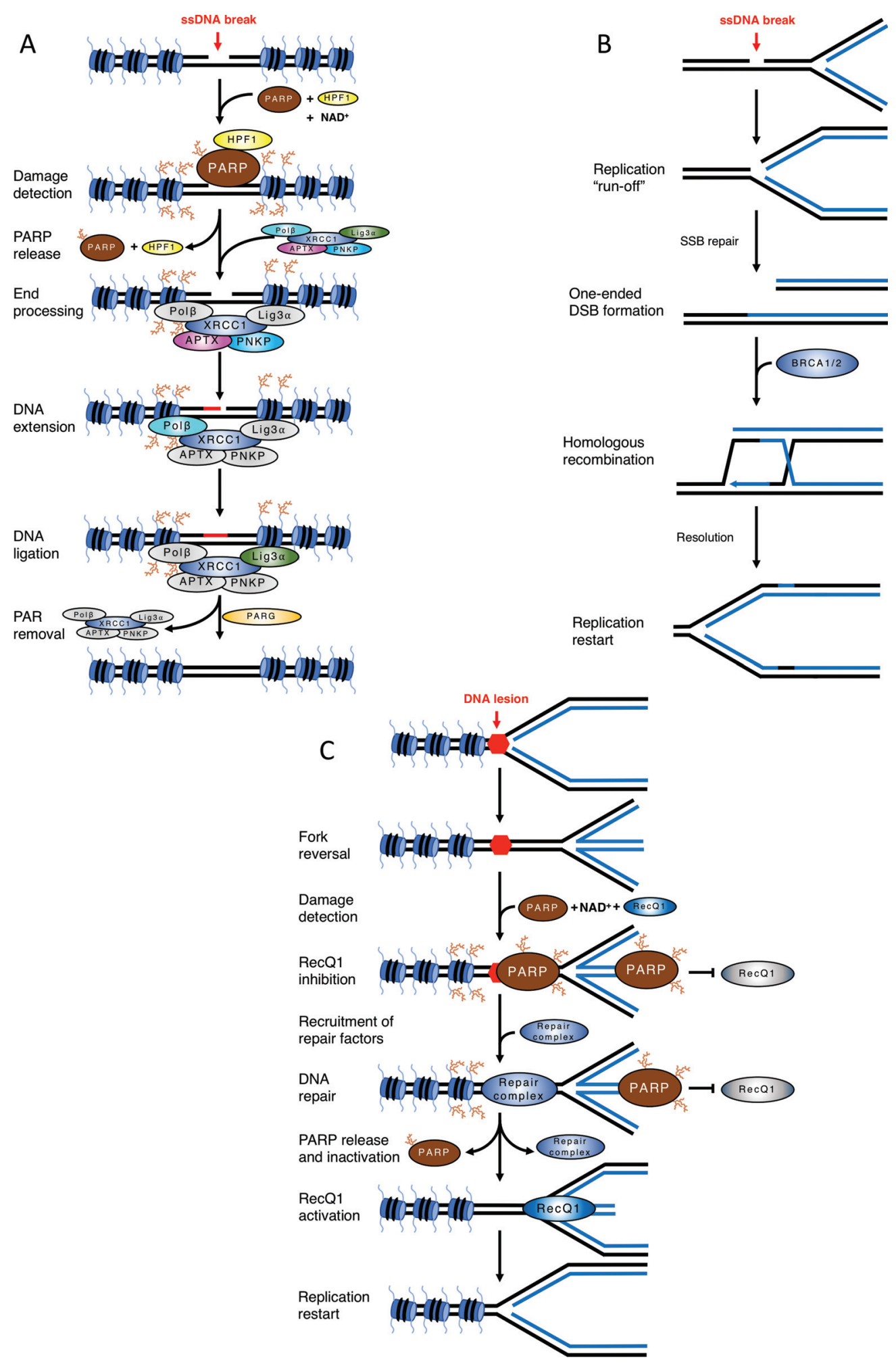

Figure 2 - Examples of the impact of ADP-ribosylation in DNA damage signalling and repair. A) Mechanism of single-strand break repair. A singlestrand break activates PARP1/2, leading to HPF-1 assisted PARylation of chromatin. PARP auto-modification causes its release and PAR chains surrounding the break site recruit XRCC1 complex. APTX and PNKP process break termini, Pol $\beta$ fills the gap by DNA synthesis and DNA Ligase III $\alpha$ seals the remaining nick. PARG removes PAR chains and XRCC1 complex is released, completing the repair. B) Defective single-strand break repair causes a reliance on homologous recombination. An unrepaired single-strand break is encountered by an ongoing replication fork, which converts it into a one-ended double-strand break. This lesion is repaired by BRCA1 and BRCA2-dependent homologous recombination. C) Role of PARP1/2 in fork reversal. A replication fork encounters an obstacle to its progression and reverts. PARP is activated either by the obstacle/lesion itself or by the DNA end at the regressed fork. PAR chains prevent RecQ1 binding/activity. Upon resolution of the block, PARP release (and presumably PAR chain degradation by PARG) allow RecQ1 helicase to access the reversed fork and remodel it back into a canonical replication fork. 
somerase poisons (Hoch et al., 2017). Surprisingly, PARP2 seems unable to modify the same target sites as PARP1, suggesting that this redundancy is indirect (Leslie Pedrioli et al., 2018). Intriguingly, a recent study suggested that PARP2 extends PARP1-generated PAR chains, introducing branching points that are recognised by branchingspecific factors (Chen et al., 2018).

The other DNA-dependent ADP-ribosyl transferase PARP3, although activated by DNA breaks in vitro, has less clear roles in DNA repair, and has been implicated in double-strand break (DSB) repair by non-homologous end-joining (Rulten et al., 2011), particularly during IgG class switching (Robert et al., 2015), regulation of DSB repair pathway choice (Beck et al., 2014b) and most recently the repair of G4-quadruplex containing DNA lesions (Day et al., 2017; Layer et al., 2018).

ADP-ribosylation also controls telomere length. TRF1, a telomere-binding protein, is PARylated by the tankyrase PARP5a (or TNKS1), which reduces its affinity for the telomere and allows telomerase to access the DNA end for elongation (Smith et al., 1998). Similarly, PARP2 has been shown to contribute to telomere homeostasis by modifying TRF2 (Dantzer et al., 2004). Other PARPs, such as PARP9, PARP10 and PARP15 also play roles in DNA repair (Yan et al., 2013; Nicolae et al., 2014; Nicolae et al., 2015), suggesting that the interplay between ADP-ribosylation and genomic stability may be even more extensive than currently known.

\section{DNA-dependent PARPs and chromatin}

PARP1 can be thought of as an integral component of chromatin that modifies chromatin structure directly (Clark et al., 2012). For example, PARP1 was shown to compete with histone $\mathrm{H} 1$ for binding to linker DNA (Poirier et al., 1982; Kim et al., 2004) and is reported to have intrinsic histone chaperone activity in vitro, mediated in part by the highly negatively charged nature of the PAR polymer (Muthurajan et al., 2014). This is further illustrated by the extensive PARP1-dependent modification of core and linker histones (Boulikas, 1988), as well as the existence of H2A variants with PAR-binding domains that may well mediate long-range PARP-dependent chromatin interactions (Timinszky et al., 2009).

PARP1 also regulates chromatin accessibility indirectly by recruiting chromatin remodellers, such as ALC1, SMARCA5 and CHD2 (Ahel et al., 2009; Smeenk et al., 2013; Luijsterburg et al., 2016). Interestingly, processing of PARP1-generated PAR chains by PARG and NUDIX5 hydrolases has been suggested to provide a localised pool of ATP in the nucleus for ATP-consuming chromatin remodelling complexes (Wright et al., 2016). PARP1 activation at gene promoters also controls the induction of transcription, such as chromatin "puffing" of heat shock-inducible genes in Drosophila polytene chromosomes (Tulin and Spradling, 2003), and at gene promoters responsive to transcription factors such as NFkB, PPAR $\gamma$ and hormone receptors such as ER, AR and RAR (Kraus and Hottiger, 2013). Recently, PARP1 has also been linked with the regulation of RNA polymerase II pausing via the negative elongation factor NELF-E (Gibson et al., 2016). However, a more precise understanding of the molecular mechanisms involved in most of these processes and reconciliation with the fact that PARP1 KO mice have very mild phenotypes are still lacking.

Although the partial redundancy between PARP1 and PARP2 is clear for DNA damage-related functions, whether this extends to chromatin remodelling and transcriptional regulation is unclear. A screen for PARP2 targets revealed an enrichment of proteins associated with transcriptional regulation and RNA splicing, suggesting this might be the case. Similarly, targets of PARP3 were enriched in RNA processing, transcription and chromatin organization (Bartolomei et al., 2016), suggesting that all three DNA-dependent PARPs may well be involved in important DNA-damage independent aspects of chromatin biology.

\section{ADP-ribose in cellular signalling}

ADP-ribosylation is also involved in controlling several signalling cascades, such as Wnt/ $\beta$-catenin, NFkB and the unfolded protein response. The two tankyrases PARP5a and PARP5b (TNKS1 and TNKS2) PARylate axin, a central component in the $\beta$-catenin destruction complex, leading to its proteasomal degradation via RNF146, a PARdependent E3 ubiquitin ligase (Huang et al., 2009). Wnt signalling is further promoted by PARP10-dependent mono-ADP-ribosylation of GSK3 $\beta$, which inhibits its kinase activity and also stabilises $\beta$-catenin (Feijs et al., 2013). PARP10 additionally suppresses $\mathrm{NF \kappa B}$ signalling via MARylation and inactivation of NEMO (Verheugd et al., 2013), and PARP16 was shown to MARylate and activate PERK and IRE1 $\alpha$, central signalling hubs in the unfolded protein response in the endoplasmic reticulum (Jwa and Chang, 2012).

Many PARPs are involved in cellular antiviral mechanisms, with PARP7, PARP9, PARP12 and PARP14 all implicated in the interferon response, and PARP13 is involved in direct degradation of viral transcripts (Atasheva et al., 2014; Welsby et al., 2014; Zhang, Y. et al., 2015; Iwata et al., 2016). Intriguingly, many of these enzymes, as well as PARP4 and PARP15, are under diversifying selective pressure in primates, suggesting an ADP-ribose "arms-race" between hosts and viral pathogens (Daugherty et al., 2014).

With the recent development of better tools to detect ADP-ribose modification of proteins (Chang, 2018), many additional roles of ADP-ribosylation in a variety of cellular signalling pathways are likely to emerge in coming years. 


\section{PARP1 and cell death}

Active PARP1 produces large amounts of PAR and at high levels of DNA damage up to $80 \%$ of the cellular NAD ${ }^{+}$ pool can be depleted within 5-15 min (D'Amours et al., 1999). Since $\mathrm{NAD}^{+}$is necessary for glyceraldehyde 3phosphate dehydrogenase activity during glycolysis (Tan et al., 2013), a reduction in $\mathrm{NAD}^{+}$leads to lower pyruvate production, reducing carbon flow into the mitochondrial TCA cycle, and hence ATP production. Conversely, ATP is required for $\mathrm{NAD}^{+}$synthesis, and therefore the uncontrolled use of $\mathrm{NAD}^{+}$by PARP1 can lead to a bioenergetic collapse (Figure 3).

PARP1 hyperactivation initiates a programmed cell death pathway termed parthanatos, which is independent of canonical apoptosis, necrosis or autophagy (Yu et al., 2002; Galluzzi et al., 2018) and is mediated by the apoptosisinducing factor (AIF) (Yu et al., 2002; Andrabi et al., 2006) (Figure 3). AIF is a mitochondrial membrane-anchored protein that is required for the assembly of the mitochondrial electron transport chain and exists in an equilibrium between monomeric and dimeric forms, with $\mathrm{NAD}(\mathrm{H})$ binding favouring dimer formation (Brosey et al., 2016). Upon PARP1 hyperactivation, AIF is released from the mitochondria and translocates to the nucleus to drive parthanatos (Yu et al., 2002; Otera et al., 2005). How this occurs is currently unclear, but surprisingly, the AIF transmembrane fragment does not need to be cleaved (Wang, Y. et $a l ., 2009)$. One possibility is that $\mathrm{NAD}^{+}$depletion itself promotes AIF release either by mitochondrial dysfunction (Alano et al., 2010; Baxter et al., 2014) or by inducing conformational changes in AIF (Sevrioukova, 2009; Brosey et al., 2016). Alternatively, a direct interaction between AIF and protein-free PAR polymers has been suggested to mediate AIF release (Andrabi et al., 2006; Wang, Y. et al., 2011). Free AIF then promotes translocation of the nuclease MIF to the nucleus, which cleaves genomic DNA inducing cell death (Wang, Y. et al., 2016a) (Figure 3). Many of the molecular mechanisms of parthanatos remain to be clarified, but an improved understanding of this pathway is critical for the development of novel treatment avenues for a potentially large number of diseases (see below).

\section{Human diseases and therapeutic opportunities}

\section{PARP1/2 inhibition and HR-defective cancer}

DNA-activated PARPs, particularly PARP1, became attractive drug target candidates for cancer therapy in 2005 when PARP inhibition (PARPi) was shown to induce synthetic lethality in cells lacking BRCA1/2 (Bryant et al., 2005; Farmer et al., 2005). As discussed above, in the absence of PARP1-dependent SSBR, unrepaired singlestrand breaks are converted into DSBs by the passage of a replication fork, leading to a distinct requirement for BRCA1/2-dependent homologous recombination (HR) (Figure 2B). BRCA genes are tumour suppressors that are

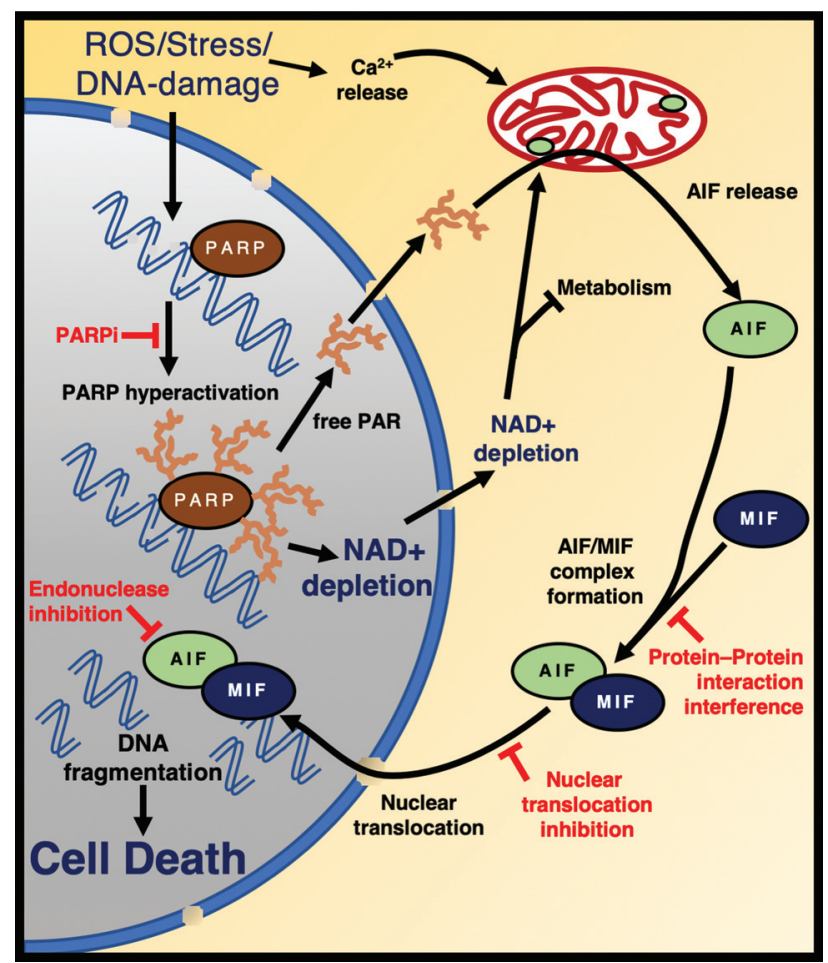

Figure 3 - PARP1 mediates cell death by Parthanatos. Oxidative damage triggers PARP-hyperactivation, resulting in AIF release from the mitochondria and nuclear translocation of the AIF/MIF complex. Endonuclease activation causes cell death. Some of the potential therapeutic targets are depicted in red. The nucleus is coloured in grey and cytoplasm in orange. AIF: Apoptosis Inducing Factor. MIF: macrophage migration inhibitory factor.

frequently mutated in breast and ovarian cancers, and four compounds (rucaparib, niraparib, olaparib and talazoparib) are currently licenced by the U.S. Food and Drug Administration (FDA) for treatment of BRCA-defective cancers (O'Connor, 2015; Bitler et al., 2017). These inhibitors bind to the nicotinamide binding site in the catalytic domain, mimicking the three H-bonds established by the nicotinamide group from $\mathrm{NAD}^{+}$. By blocking PARP catalytic activity, these compounds slow single-strand break repair in two ways: a) the lack of PARylation surrounding break sites delays the recruitment of DNA repair factors such as XRCC1; and b) by preventing PARP1 auto-modification that is required for release of the protein from the DNA break (D'Amours et al., 1999). Thus, these inhibitors lock or "trap" the enzyme bound to the DNA, preventing the access of other enzymes to the break (Bryant et al., 2005; Pommier et al., 2016; Lord and Ashworth, 2017). Novel inhibitors that induce more stable trapping of PARP seem to be better inducers of synthetic lethality in BRCA-mutated cells, suggesting that this trapping effect is crucial for PARP inhibitor efficacy (Murai et al., 2014).

The clinical success of PARP inhibitors in BRCA1/2-mutated breast and ovarian cancers has ignited a push for more widespread use of these compounds in cancers with a molecular signature of defective HR, irrespec- 
tive of which HR gene is mutated and in which tissue the tumour originated (Pilie et al., 2019). Similarly, novel inhibitors that selectively target different PARPs, including PARP3, PARP5a/5b, PARP7, PARP10, PARP11 and PARP14 are under investigation for the targeted treatment of cancers with alterations in particular pathways (Ishida et al., 2006; Lindgren et al., 2013; Iwata et al., 2016; Wang, Y. Q. et al., 2016b; Ferri et al., 2017; Yoneyama-Hirozane et al., 2017; Kirby et al., 2018; Moustakim et al., 2018; Murthy et al., 2018).

Remarkably, PARP1 inhibitors may also be of significant therapeutic value for non-oncological use both in rare neurological disorders in which excessive PARP signalling seems to be detrimental, as well as in more prevalent degenerative diseases in which parthanatos seems to play a central pathological role (Berger et al., 2018) (discussed below).

\section{ADP-ribosylation in genetic neurodegenerative disorders}

Mutations in single-strand break repair genes, such as PNKP, APTX, TDP1 and XRCC1, cause genetic neurodegenerative disorders characterised by severe cerebellar atrophy and ataxia (Moreira et al., 2001; El-Khamisy et al., 2005; Bras et al., 2015; Hoch et al., 2017). Treatment of cells from these patients with DNA damaging agents leads to excessive PARP1 activation, suggesting that defective single-strand break repair leads to overt signalling of these lesions (Hoch et al., 2017). As deletion of PARP1 partially rescued many of the cerebellar defects observed in XRCC1-deficient mice, it was suggested that PARP1-induced parthanatos and/or $\mathrm{NAD}^{+}$depletion contributes to disease pathology (Hoch et al., 2017). Although PARP1 inhibition should in principle be beneficial in this scenario, the currently available PARP1 inhibitors are unlikely to be of therapeutic value, as the PARP1 trapping effect (discussed above) further compounds the DNA repair defect in these cells (Hoch et al., 2017). In this context, inhibitors that better mimic genetic deletion of PARP1 would be desirable.

Mutations in enzymes involved in removing ADPribose modifications also leads to neurodegenerative disease, as illustrated by the identification of patients with mutations in the hydrolases ARH3 and TARG. ARH3 has specificity for both poly-ADP-ribose chains as well as mono-ADP-ribose moieties attached to serines (Abplanalp et al., 2017; Fontana et al., 2017), whereas TARG hydrolyses the ester linkage between mono-ADP-ribose and aspartate or glutamate side chains (Sharifi et al., 2013). ARH3 mutations are associated with neurodegenerative defects such as ataxia and febrile seizures, while TARG1 loss causes severe developmental delay, epilepsy and quadriplegia (Sharifi et al., 2013; Danhauser et al., 2018; Ghosh et al., 2018). Whereas TARG deficient cells shown signs of DNA-repair defects, a role for ARH3 in DNA damage re- sponses is speculative at this point, although serine has been recently established as the primary acceptor of DNA damage-induced ADP-ribosylation (Palazzo et al., 2018). If excessive PAR formation, $\mathrm{NAD}^{+}$depletion and/or parthanatos are also involved in promoting the neurological defects seen in these patients, currently available catalytic PARP1 inhibitors may well be a viable therapeutic option (Danhauser et al., 2018; Ghosh et al., 2018).

Mutations in PARP10 lead to a neurodegenerative disorder associated with developmental delay and cortical atrophy, as well as delayed myelination (Shahrour et al., 2016). Although a defect in PARP10-dependent Wnt or NFкB signalling was not determined, patient cells had a DNA repair defect in response to hydroxyurea (HU) and ultraviolet light (UV), and the pathology is reminiscent of other DNA repair disorders (Shahrour et al., 2016). A more detailed understanding of the cellular consequences of PARP10 loss and which of its many functions is most important to prevent disease onset and progression will be critical to suggest possible therapeutic avenues for this disease.

\section{Parthanatos inhibition}

PARP1-dependent cell death via parthanatos has been implicated in several critical pathological processes, such as ischemia-reperfusion injury in myocardial infarction and stroke, septic shock, brain trauma and neurodegenerative diseases such as Parkinsons disease and Alzheimers disease (Pacher and Szabo, 2007; Moroni, 2008; Lee et al., 2013; Dawson and Dawson, 2017; Berger et al., 2018; Henning et al., 2018; Kam et al., 2018; Zhang, J. et al., 2018). A common theme among these disorders seems to be PARP1 hyperactivation in response to oxidative DNA damage, either as part of the reperfusion of oxygen-deprived tissues or caused by pathophysiological changes that induce the production of reactive oxygen species or nitric oxide.

Interestingly, PARP1 cytotoxicity seems to have a gender bias (McCullough et al., 2005; Yuan et al., 2009), with androgens promoting parthanatos (Vagnerova et al., 2010; Sharma et al., 2011), while oestrogens counteract it (Batnasan et al., 2015). This raises the fascinating possibility that differential sensitivity to PARP1 hyperactivation might contribute to the higher male incidence of ischaemic stroke, sepsis and Parkinsons disease (Miller and CroninGolomb, 2010; Sakr et al., 2013; Barker-Collo et al., 2015).

Mounting pre-clinical evidence suggests that PARP1 knockout or PARP inhibitor treatment have profound beneficial effects in mouse models of parthanatos-induced pathologies, preventing cell death and tissue dysfunction (Pacher and Szabo, 2007; Dawson and Dawson, 2017; Berger et al., 2018; Henning et al., 2018). These results have prompted calls for clinical trials to repurpose PARP inhibitors for the treatment of these disorders, particularly when no other viable treatment option exists (Berger et al., 
2018). Conceptually, targeting other steps in parthanatos, such as preventing mitochondrial AIF release or inhibiting nuclear import or activation of the MIF nuclease may also be of therapeutic value (Figure 3). Although these compounds would have to undergo extensive pre-clinical and clinical efficacy and safety trials, their development may be warranted by a reduced potential for DNA repair-associated side-effects of systemic PARP inhibition during chronic treatment.

\section{Concluding remarks}

Detailed knowledge of the processes and pathways regulated by post-translational modifications such as phosphorylation and ubiquitination led to the development of a myriad of kinase inhibitors and molecules targeting the ubiquitin system, either already in clinical use or in clinical trials (Ferguson and Gray, 2018; Wertz and Wang, 2019). In recent years, novel tools to study ADP-ribosylation have allowed a rapid development in this field, characterising many of the "writers", "erasers" and "readers" of this modification. Taken together with the fact that the first PARP inhibitor only entered the clinic in 2014, this raises the exciting prospect that a more detailed understanding of ADP-ribose metabolism, particularly of less well-studied PARPs and hydrolases, may well yield novel therapeutic strategies in coming years.

\section{Acknowledgments}

The authors would like to thank Prof. Keith Caldecott for critical reading of the manuscript and apologize to the many important studies that could not be cited or described in depth here. Work in the NCH lab is funded by grants from FAPESP (2018/18007-5) and CNPq (407765/20182). LMPs work was supported by Cancer Research UK Programme grant C302/A24386.

\section{Conflict of Interest}

The authors declare that there is no conflict of interest that could be perceived as prejudicial to the impartiality of this review.

\section{Author contributions}

Both authors contributed equally to the writing of this manuscript.

\section{References}

Abplanalp J, Leutert M, Frugier E, Nowak K, Feurer R, Kato J, Kistemaker HVA, Filippov DV, Moss J, Caflisch A et al. (2017) Proteomic analyses identify ARH3 as a serine mono-ADP-ribosylhydrolase. Nat Commun 8:2055.

Ahel D, Horejsi Z, Wiechens N, Polo SE, Garcia-Wilson E, Ahel I, Flynn H, Skehel M, West SC, Jackson SP et al. (2009) Poly(ADP-ribose)-dependent regulation of DNA repair by the chromatin remodeling enzyme ALC1. Science 325:1240-1243.

Alano CC, Garnier P, Ying W, Higashi Y, Kauppinen TM and Swanson RA (2010) NAD+ depletion is necessary and sufficient for poly(ADP-ribose) polymerase-1-mediated neuronal death. J Neurosci 30:2967-2978.

Ali AAE, Timinszky G, Arribas-Bosacoma R, Kozlowski M, Hassa PO, Hassler M, Ladurner AG, Pearl LH and Oliver AW (2012) The zinc-finger domains of PARP1 cooperate to recognize DNA strand breaks. Nat Struct Mol Biol 19:685692.

Altmeyer M, Messner S, Hassa PO, Fey M and Hottiger MO (2009) Molecular mechanism of poly(ADP-ribosyl)ation by PARP1 and identification of lysine residues as ADP-ribose acceptor sites. Nucleic Acids Res 37:3723-3738.

Altmeyer M, Neelsen KJ, Teloni F, Pozdnyakova I, Pellegrino S, Grofte M, Rask MB, Streicher W, Jungmichel S, Nielsen ML et al. (2015) Liquid demixing of intrinsically disordered proteins is seeded by poly(ADP-ribose). Nat Commun 6:8088.

Andrabi SA, Kim NS, Yu SW, Wang H, Koh DW, Sasaki M, Klaus JA, Otsuka T, Zhang Z, Koehler RC et al. (2006) Poly(ADP-ribose) (PAR) polymer is a death signal. Proc Natl Acad Sci U S A 103:18308-18313.

Atasheva S, Frolova EI and Frolov I (2014) Interferon-stimulated poly(ADP-Ribose) polymerases are potent inhibitors of cellular translation and virus replication. J Virol 88:2116-2130.

Barkauskaite E, Jankevicius G and Ahel I (2015) Structures and mechanisms of enzymes employed in the synthesis and degradation of PARP-dependent protein ADP-ribosylation. Mol Cell 58:935-946.

Barker-Collo S, Bennett DA, Krishnamurthi RV, Parmar P, Feigin VL, Naghavi M, Forouzanfar MH, Johnson CO, Nguyen G, Mensah GA et al. (2015) Sex differences in stroke incidence, prevalence, mortality and disability-adjusted life years: Results from the Global Burden of Disease Study 2013. Neuroepidemiology 45:203-214.

Bartolomei G, Leutert M, Manzo M, Baubec T and Hottiger MO (2016) Analysis of chromatin ADP-ribosylation at the genome-wide level and at specific loci by ADPr-ChAP. Mol Cell 61:474-485.

Batnasan E, Wang R, Wen J, Ke Y, Li X, Bohio AA, Zeng X, Huo H, Han L, Boldogh I et al. (2015) 17-beta estradiol inhibits oxidative stress-induced accumulation of AIF into nucleolus and PARP1-dependent cell death via estrogen receptor alpha. Toxicol Lett 232:1-9.

Baxter P, Chen Y, Xu Y and Swanson RA (2014) Mitochondrial dysfunction induced by nuclear poly(ADP-ribose) polymerase-1: a treatable cause of cell death in stroke. Transl Stroke Res 5:136-144.

Beck C, Robert I, Reina-San-Martin B, Schreiber V and Dantzer F (2014a) Poly(ADP-ribose) polymerases in double-strand break repair: focus on PARP1, PARP2 and PARP3. Exp Cell Res 329:18-25.

Beck C, Boehler C, Guirouilh Barbat J, Bonnet ME, Illuzzi G, Ronde P, Gauthier LR, Magroun N, Rajendran A, Lopez BS et al. (2014b) PARP3 affects the relative contribution of homologous recombination and nonhomologous end-joining pathways. Nucleic Acids Res 42:5616-5632.

Belousova EA, Ishchenko AA and Lavrik OI (2018) DNA is a new target of PARP3. Sci Rep 8:4176. 
Benjamin RC and Gill DM (1980a) ADP-ribosylation in mammalian cell ghosts. Dependence of poly(ADP-ribose) synthesis on strand breakage in DNA. J Biol Chem 255:10493-10501.

Benjamin RC and Gill DM (1980b) Poly(ADP-ribose) synthesis in vitro programmed by damaged DNA. A comparison of DNA molecules containing different types of strand breaks. J Biol Chem 255:10502-10508.

Berger NA, Besson VC, Boulares AH, Burkle A, Chiarugi A, Clark RS, Curtin NJ, Cuzzocrea S, Dawson TM, Dawson VL et al. (2018) Opportunities for the repurposing of PARP inhibitors for the therapy of non-oncological diseases. Br J Pharmacol 175:192-222.

Berti M, Ray Chaudhuri A, Thangavel S, Gomathinayagam S, Kenig S, Vujanovic M, Odreman F, Glatter T, Graziano S, Mendoza-Maldonado R et al. (2013) Human RECQ1 promotes restart of replication forks reversed by DNA topoisomerase I inhibition. Nat Struct Mol Biol 20:347-354.

Bitler BG, Watson ZL, Wheeler LJ and Behbakht K (2017) PARP inhibitors: Clinical utility and possibilities of overcoming resistance. Gynecol Oncol 147:695-704.

Bonfiglio JJ, Fontana P, Zhang Q, Colby T, Gibbs-Seymour I, Atanassov I, Bartlett E, Zaja R, Ahel I and Matic I (2017) Serine ADP-ribosylation depends on HPF1. Mol Cell 65:932-940 e936.

Boulikas T (1988) At least 60 ADP-ribosylated variant histones are present in nuclei from dimethylsulfate-treated and untreated cells. EMBO J 7:57-67.

Bras J, Alonso I, Barbot C, Costa MM, Darwent L, Orme T, Sequeiros J, Hardy J, Coutinho P and Guerreiro R (2015) Mutations in PNKP cause recessive ataxia with oculomotor apraxia type 4. Am J Hum Genet 96:474-479.

Breslin C, Hornyak P, Ridley A, Rulten SL, Hanzlikova H, Oliver AW and Caldecott KW (2015) The XRCC1 phosphatebinding pocket binds poly (ADP-ribose) and is required for XRCC1 function. Nucleic Acids Res 43:6934-6944.

Brosey CA, Ho C, Long WZ, Singh S, Burnett K, Hura GL, Nix JC, Bowman GR, Ellenberger T and Tainer JA (2016) Defining NADH-Driven Allostery Regulating ApoptosisInducing Factor. Structure 24:2067-2079.

Bryant HE, Schultz N, Thomas HD, Parker KM, Flower D, Lopez E, Kyle S, Meuth M, Curtin NJ and Helleday T (2005) Specific killing of BRCA2-deficient tumours with inhibitors of poly(ADP-ribose) polymerase. Nature 434:913-917.

Bryant HE, Petermann E, Schultz N, Jemth AS, Loseva O, Issaeva N, Johansson F, Fernandez S, McGlynn P and Helleday T (2009) PARP is activated at stalled forks to mediate Mre11dependent replication restart and recombination. EMBO J 28:2601-2615.

Caldecott KW (2008) Single-strand break repair and genetic disease. Nat Rev Genet 9:619-631.

Caldecott KW (2014) Protein ADP-ribosylation and the cellular response to DNA strand breaks. DNA Repair (Amst) 19:108-113.

Chambon P, Weill JD and Mandel P (1963) Nicotinamide mononucleotide activation of new DNA-dependent polyadenylic acid synthesizing nuclear enzyme. Biochem Biophys Res Commun 11:39-43

Chang P (2018) ADP-ribosylation and NAD+ Utilizing Enzymes: Methods and Protocols. Methods in Molecular Biology. 1st edition. Humana Press, New York.
Chen Q, Kassab MA, Dantzer F and Yu X (2018) PARP2 mediates branched poly ADP-ribosylation in response to DNA damage. Nat Commun 9:3233.

Cheng Q, Barboule N, Frit P, Gomez D, Bombarde O, Couderc B, Ren GS, Salles B and Calsou P (2011) Ku counteracts mobilization of PARP1 and MRN in chromatin damaged with DNA double-strand breaks. Nucleic Acids Res 39:96059619.

Clark NJ, Kramer M, Muthurajan UM and Luger K (2012) Alternative modes of binding of poly(ADP-ribose) polymerase 1 to free DNA and nucleosomes. J Biol Chem 287:3243032439.

Cohen MS and Chang P (2018) Insights into the biogenesis, function, and regulation of ADP-ribosylation. Nat Chem Biol 14:236-243.

Cortes-Ledesma F and Aguilera A (2006) Double-strand breaks arising by replication through a nick are repaired by cohesin-dependent sister-chromatid exchange. EMBO Rep 7:919-926.

D’Amours D, Desnoyers S, D'Silva I and Poirier GG (1999) Poly(ADP-ribosyl)ation reactions in the regulation of nuclear functions. Biochem J 342 (Pt 2):249-268.

Danhauser K, Alhaddad B, Makowski C, PiekutowskaAbramczuk D, Syrbe S, Gomez-Ospina N, Manning MA, Kostera-Pruszczyk A, Krahn-Peper C, Berutti R et al. (2018) Bi-allelic ADPRHL2 mutations cause neurodegeneration with developmental delay, araxia and axonal neuropathy. Am J Hum Genet 103:817-825.

Dantzer F, Giraud-Panis MJ, Jaco I, Ame JC, Schultz I, Blasco M, Koering CE, Gilson E, Menissier-de Murcia J, de Murcia G et al. (2004) Functional interaction between poly(ADP-Ribose) polymerase 2 (PARP-2) and TRF2: PARP activity negatively regulates TRF2. Mol Cell Biol 24:1595-1607.

DaRosa PA, Wang Z, Jiang X, Pruneda JN, Cong F, Klevit RE and $\mathrm{Xu}$ W (2015) Allosteric activation of the RNF146 ubiquitin ligase by a poly(ADP-ribosyl)ation signal. Nature 517:223226.

Daugherty MD, Young JM, Kerns JA and Malik HS (2014) Rapid evolution of PARP genes suggests a broad role for ADPribosylation in host-virus conflicts. PLoS Genet 10:e1004403.

Dawicki-McKenna JM, Langelier MF, DeNizio JE, Riccio AA, Cao CD, Karch KR, McCauley M, Steffen JD, Black BE and Pascal JM (2015) PARP-1 activation requires local unfolding of an autoinhibitory domain. Mol Cell 60:755-768.

Dawson TM and Dawson VL (2017) Mitochondrial mechanisms of neuronal cell death: Potential therapeutics. Annu Rev Pharmacol Toxicol 57:437-454.

Day TA, Layer JV, Cleary JP, Guha S, Stevenson KE, Tivey T, Kim S, Schinzel AC, Izzo F, Doench J et al. (2017) PARP3 is a promoter of chromosomal rearrangements and limits G4 DNA. Nat Commun 8:15110.

El-Khamisy SF, Saifi GM, Weinfeld M, Johansson F, Helleday T, Lupski JR and Caldecott KW (2005) Defective DNA single-strand break repair in spinocerebellar ataxia with axonal neuropathy-1. Nature 434:108-113.

Eustermann S, Wu WF, Langelier MF, Yang JC, Easton LE, Riccio AA, Pascal JM and Neuhaus D (2015) Structural basis of detection and signaling of DNA single-strand breaks by human PARP-1. Mol Cell 60:742-754. 
Farmer H, McCabe N, Lord CJ, Tutt AN, Johnson DA, Richardson TB, Santarosa M, Dillon KJ, Hickson I, Knights C et al. (2005) Targeting the DNA repair defect in BRCA mutant cells as a therapeutic strategy. Nature 434:917-921.

Feijs KL, Kleine H, Braczynski A, Forst AH, Herzog N, Verheugd P, Linzen U, Kremmer E and Luscher B (2013) ARTD10 substrate identification on protein microarrays: regulation of GSK3beta by mono-ADP-ribosylation. Cell Commun Signal 11:5.

Ferguson FM and Gray NS (2018) Kinase inhibitors: the road ahead. Nat Rev Drug Discov 17:353-377.

Ferri M, Liscio P, Carotti A, Asciutti S, Sardella R, Macchiarulo A and Camaioni E (2017) Targeting Wnt-driven cancers: Discovery of novel tankyrase inhibitors. Eur J Med Chem 142:506-522.

Fontana P, Bonfiglio JJ, Palazzo L, Bartlett E, Matic I and Ahel I (2017) Serine ADP-ribosylation reversal by the hydrolase ARH3. eLife 6:e28533.

Galluzzi L, Vitale I, Aaronson SA, Abrams JM, Adam D, Agostinis P, Alnemri ES, Altucci L, Amelio I, Andrews DW et al. (2018) Molecular mechanisms of cell death: recommendations of the Nomenclature Committee on Cell Death 2018. Cell Death Differ 25:486-541.

Ghosh SG, Becker K, Huang H, Dixon-Salazar T, Chai G, Salpietro $\mathrm{V}$, Al-Gazali L, Waisfisz Q, Wang H, Vaux KK et al. (2018) Biallelic mutations in ADPRHL2, encoding ADP-ribosylhydrolase 3, lead to a degenerative pediatric stress-induced epileptic ataxia syndrome . Am J Hum Genet 103:826.

Gibbs-Seymour I, Fontana P, Rack JGM and Ahel I (2016) HPF1/C4orf27 is a PARP-1-interacting protein that regulates PARP-1 ADP-ribosylation activity. Mol Cell 62:432442.

Gibson BA and Kraus WL (2012) New insights into the molecular and cellular functions of poly(ADP-ribose) and PARPs. Nat Rev Mol Cell Biol 13:411-424.

Gibson BA and Kraus WL (2017) Identification of protein substrates of specific PARP enzymes using analog-sensitive PARP mutants and a "clickable" $\mathrm{NAD}(+)$ analog. Methods Mol Biol 1608:111-135.

Gibson BA, Zhang Y, Jiang H, Hussey KM, Shrimp JH, Lin H, Schwede F, Yu Y and Kraus WL (2016) Chemical genetic discovery of PARP targets reveals a role for PARP-1 in transcription elongation. Science 353:45-50.

Grundy GJ, Polo LM, Zeng Z, Rulten SL, Hoch NC, Paomephan $\mathrm{P}, \mathrm{Xu}$ Y, Sweet SM, Thorne AW, Oliver AW et al. (2016) PARP3 is a sensor of nicked nucleosomes and monoribosylates histone H2B(Glu2). Nat Commun 7:12404.

Haince JF, McDonald D, Rodrigue A, Dery U, Masson JY, Hendzel MJ and Poirier GG (2008) PARP1-dependent kinetics of recruitment of MRE11 and NBS1 proteins to multiple DNA damage sites. J Biol Chem 283:1197-1208.

Hanzlikova H, Gittens W, Krejcikova K, Zeng Z and Caldecott KW (2017) Overlapping roles for PARP1 and PARP2 in the recruitment of endogenous XRCC1 and PNKP into oxidized chromatin. Nucleic Acids Res 45:2546-2557.

Hanzlikova H, Kalasova I, Demin AA, Pennicott LE, Cihlarova Z and Caldecott KW (2018) The importance of poly(ADP-ribose) polymerase as a sensor of unligated Okazaki fragments during DNA replication. Mol Cell 71:319-331.e3.
Henning RJ, Bourgeois M and Harbison RD (2018) Poly(ADPribose) Polymerase (PARP) and PARP inhibitors: Mechanisms of action and role in cardiovascular disorders. Cardiovasc Toxicol 18:493-506.

Hoch NC, Hanzlikova H, Rulten SL, Tetreault M, Komulainen E, Ju L, Hornyak P, Zeng Z, Gittens W, Rey SA et al. (2017) $\mathrm{XRCC} 1$ mutation is associated with PARP1 hyperactivation and cerebellar ataxia. Nature 541:87-91.

Hochegger H, Dejsuphong D, Fukushima T, Morrison C, Sonoda E, Schreiber V, Zhao GY, Saberi A, Masutani M, Adachi N et al. (2006) Parp-1 protects homologous recombination from interference by $\mathrm{Ku}$ and Ligase IV in vertebrate cells. EMBO J 25:1305-1314.

Hsu PC, Gopinath RK, Hsueh YA and Shieh SY (2019) CHK2mediated regulation of PARP1 in oxidative DNA damage response. Oncogene 38:1166-1182.

Huang SM, Mishina YM, Liu S, Cheung A, Stegmeier F, Michaud GA, Charlat O, Wiellette E, Zhang Y, Wiessner S et al. (2009) Tankyrase inhibition stabilizes axin and antagonizes Wnt signalling. Nature 461:614-620.

Ishida J, Yamamoto H, Kido Y, Kamijo K, Murano K, Miyake H, Ohkubo M, Kinoshita T, Warizaya M, Iwashita A et al. (2006) Discovery of potent and selective PARP-1 and PARP-2 inhibitors: SBDD analysis via a combination of $\mathrm{X}$-ray structural study and homology modeling. Bioorg Med Chem 14:1378-1390.

Iwata H, Goettsch C, Sharma A, Ricchiuto P, Goh WW, Halu A, Yamada I, Yoshida H, Hara T, Wei M et al. (2016) PARP9 and PARP14 cross-regulate macrophage activation via STAT1 ADP-ribosylation. Nat Commun 7:12849.

Juarez-Salinas H, Levi V, Jacobson EL and Jacobson MK (1982) Poly(ADP-ribose) has a branched structure in vivo. J Biol Chem 257:607-609.

Jwa M and Chang P (2012) PARP16 is a tail-anchored endoplasmic reticulum protein required for the PERK- and IRE1alpha-mediated unfolded protein response. Nat Cell Biol 14:1223-1230.

Kam TI, Mao X, Park H, Chou SC, Karuppagounder SS, Umanah GE, Yun SP, Brahmachari S, Panicker N, Chen R et al. (2018) Poly(ADP-ribose) drives pathologic alpha-synuclein neurodegeneration in Parkinson's disease. Science 362:eaat8407.

Karlberg T, Langelier MF, Pascal JM and Schuler H (2013) Structural biology of the writers, readers, and erasers in monoand poly(ADP-ribose) mediated signaling. Mol Aspects Med 34:1088-1108.

Kim MY, Mauro S, Gevry N, Lis JT and Kraus WL (2004) NAD+-dependent modulation of chromatin structure and transcription by nucleosome binding properties of PARP-1. Cell 119:803-814.

Kirby IT, Kojic A, Arnold MR, Thorsell AG, Karlberg T, Vermehren-Schmaedick A, Sreenivasan R, Schultz C, Schuler $\mathrm{H}$ and Cohen MS (2018) A A potent and selective PARP1 inhibitor suggests coupling between cellular localization and catalytic activity. Cell Chem Biol 25:1547-1553.e12.

Kraus WL (2015) PARPs and ADP-Ribosylation: 50 years ... and counting. Mol Cell 58:902-910.

Kraus WL and Hottiger MO (2013) PARP-1 and gene regulation: progress and puzzles. Mol Aspects Med 34:1109-1123.

Laing S, Unger M, Koch-Nolte F and Haag F (2011) ADPribosylation of arginine. Amino Acids 41:257-269. 
Langelier MF, Riccio AA and Pascal JM (2014) PARP-2 and PARP-3 are selectively activated by 5' phosphorylated DNA breaks through an allosteric regulatory mechanism shared with PARP-1. Nucleic Acids Res 42:7762-7775.

Langelier MF, Eisemann T, Riccio AA and Pascal JM (2018) PARP family enzymes: regulation and catalysis of the poly(ADP-ribose) posttranslational modification. Curr Opin Struct Biol 53:187-198.

Layer JV, Cleary JP, Brown AJ, Stevenson KE, Morrow SN, Van Scoyk A, Blasco RB, Karaca E, Meng FL, Frock RL et al. (2018) Parp3 promotes long-range end joining in murine cells. Proc Natl Acad Sci U S A 115:10076-10081.

Lee Y, Karuppagounder SS, Shin JH, Lee YI, Ko HS, Swing D, Jiang H, Kang SU, Lee BD, Kang HC et al. (2013) Parthanatos mediates AIMP2-activated age-dependent dopaminergic neuronal loss. Nat Neurosci 16:1392-1400.

Leidecker O, Bonfiglio JJ, Colby T, Zhang Q, Atanassov I, Zaja R, Palazzo L, Stockum A, Ahel I and Matic I (2016) Serine is a new target residue for endogenous ADP-ribosylation on histones. Nat Chem Biol 12:998-1000.

Leslie Pedrioli DM, Leutert M, Bilan V, Nowak K, Gunasekera K, Ferrari E, Imhof R, Malmstrom L and Hottiger MO (2018) Comprehensive ADP-ribosylome analysis identifies tyrosine as an ADP-ribose acceptor site. EMBO Rep 19:e45310.

Lindgren AE, Karlberg T, Thorsell AG, Hesse M, Spjut S, Ekblad $\mathrm{T}$, Andersson CD, Pinto AF, Weigelt J, Hottiger MO et al. (2013) PARP inhibitor with selectivity toward ADP-ribosyltransferase ARTD3/PARP3. ACS Chem Biol 8:16981703.

Liu Y, Kadyrov FA and Modrich P (2011) PARP-1 enhances the mismatch-dependence of 5'-directed excision in human mismatch repair in vitro. DNA Repair (Amst) 10:11451153.

Lord CJ and Ashworth A (2017) PARP inhibitors: Synthetic lethality in the clinic. Science 355:1152-1158.

Luijsterburg MS, de Krijger I, Wiegant WW, Shah RG, Smeenk G, de Groot AJL, Pines A, Vertegaal ACO, Jacobs JJL, Shah GM et al. (2016) PARP1 links CHD2-mediated chromatin expansion and H3.3 deposition to DNA repair by nonhomologous end-joining. Mol Cell 61:547-562.

Marsischky GT, Wilson BA and Collier RJ (1995) Role of glutamic acid 988 of human poly-ADP-ribose polymerase in polymer formation. Evidence for active site similarities to the ADP-ribosylating toxins. J Biol Chem 270:3247-3254.

McCullough LD, Zeng Z, Blizzard KK, Debchoudhury I and Hurn PD (2005) Ischemic nitric oxide and poly (ADPribose) polymerase- 1 in cerebral ischemia: male toxicity, female protection. J Cereb Blood Flow Metab 25:502-512.

Menissier de Murcia J, Ricoul M, Tartier L, Niedergang C, Huber A, Dantzer F, Schreiber V, Ame JC, Dierich A, LeMeur M et al. (2003) Functional interaction between PARP-1 and PARP-2 in chromosome stability and embryonic development in mouse. EMBO J 22:2255-2263.

Miller IN and Cronin-Golomb A (2010) Gender differences in Parkinson's disease: clinical characteristics and cognition. Mov Disord 25:2695-2703.

Moreira MC, Barbot C, Tachi N, Kozuka N, Uchida E, Gibson T, Mendonca P, Costa M, Barros J, Yanagisawa T et al. (2001) The gene mutated in ataxia-ocular apraxia 1 encodes the new HIT/Zn-finger protein aprataxin. Nat Genet 29:189193.
Morgan RK and Cohen MS (2015) A clickable aminooxy probe for monitoring cellular ADP-ribosylation. ACS Chem Biol 10:1778-1784.

Moroni F (2008) Poly(ADP-ribose)polymerase 1 (PARP-1) and postischemic brain damage. Curr Opin Pharmacol 8:96-103.

Moustakim M, Riedel K, Schuller M, Gehring AP, Monteiro OP, Martin SP, Fedorov O, Heer J, Dixon DJ, Elkins JM et al. (2018) Discovery of a novel allosteric inhibitor scaffold for polyadenosine-diphosphate-ribose polymerase 14 (PARP14) macrodomain 2. Bioorg Med Chem 26:29652972.

Munnur D and Ahel I (2017) Reversible mono-ADP-ribosylation of DNA breaks. FEBS J 284:4002-4016.

Murai J, Huang SY, Renaud A, Zhang Y, Ji J, Takeda S, Morris J, Teicher B, Doroshow JH and Pommier Y (2014) Stereospecific PARP trapping by BMN 673 and comparison with olaparib and rucaparib. Mol Cancer Ther 13:433-443.

Murthy S, Desantis J, Verheugd P, Maksimainen MM, Venkannagari H, Massari S, Ashok Y, Obaji E, Nkizinkinko Y, Luscher B et al. (2018) 4-(Phenoxy) and 4-(benzyloxy)benzamides as potent and selective inhibitors of mono-ADPribosyltransferase PARP10/ARTD10. Eur J Med Chem 156:93-102.

Muthurajan UM, Hepler MR, Hieb AR, Clark NJ, Kramer M, Yao $\mathrm{T}$ and Luger K (2014) Automodification switches PARP-1 function from chromatin architectural protein to histone chaperone. Proc Natl Acad Sci U S A 111:12752-12757.

Nicolae CM, Aho ER, Vlahos AH, Choe KN, De S, Karras GI and Moldovan GL (2014) The ADP-ribosyltransferase PARP10/ARTD10 interacts with proliferating cell nuclear antigen (PCNA) and is required for DNA damage tolerance. J Biol Chem 289:13627-13637.

Nicolae CM, Aho ER, Choe KN, Constantin D, Hu HJ, Lee D, Myung K and Moldovan GL (2015) A novel role for the mono-ADP-ribosyltransferase PARP14/ARTD8 in promoting homologous recombination and protecting against replication stress. Nucleic Acids Res 43:3143-3153.

Noren Hooten N, Kompaniez K, Barnes J, Lohani A and Evans MK (2011) Poly(ADP-ribose) polymerase 1 (PARP-1) binds to 8-oxoguanine-DNA glycosylase (OGG1). J Biol Chem 286:44679-44690.

O'Connor MJ (2015) Targeting the DNA damage response in cancer. Mol Cell 60:547-560.

Obaji E, Haikarainen T and Lehtio L (2018) Structural basis for DNA break recognition by ARTD2/PARP2. Nucleic Acids Res 46:12154-12165.

Ogata N, Ueda K and Hayaishi O (1980) ADP-ribosylation of histone H2B. Identification of glutamic acid residue 2 as the modification site. J Biol Chem 255:7610-7615.

Otera H, Ohsakaya S, Nagaura Z, Ishihara N and Mihara K (2005) Export of mitochondrial AIF in response to proapoptotic stimuli depends on processing at the intermembrane space. EMBO J 24:1375-1386.

Pacher P and Szabo C (2007) Role of poly(ADP-ribose) polymerase 1 (PARP-1) in cardiovascular diseases: the therapeutic potential of PARP inhibitors. Cardiovasc Drug Rev 25:235260.

Palazzo L, Leidecker O, Prokhorova E, Dauben H, Matic I and Ahel I (2018) Serine is the major residue for ADP-ribosylation upon DNA damage. Elife 7:e34334. 
Pilie P, Gay CM, Byers LA, O'Connor MJ and Yap TA (2019) PARP inhibitors: Extending benefits beyond BRCA mutant cancers. Clin Cancer Res 25:3759-3771.

Poirier GG, de Murcia G, Jongstra-Bilen J, Niedergang C and Mandel P (1982) Poly(ADP-ribosyl)ation of polynucleosomes causes relaxation of chromatin structure. Proc Natl Acad Sci U S A 79:3423-3427.

Polo LM, Xu Y, Hornyak P, Garces F, Zeng Z, Hailstone R, Matthews SJ, Caldecott KW, Oliver AW and Pearl LH (2019) Efficient single-strand break repair requires binding to both Poly(ADP-ribose) and DNA by the central BRCT domain of XRCC1. Cell Rep 26:573-581.e5.

Pommier Y, O'Connor MJ and de Bono J (2016) Laying a trap to kill cancer cells: PARP inhibitors and their mechanisms of action. Sci Transl Med 8:362ps17.

Quinet A, Lemacon D and Vindigni A (2017) Replication fork reversals: Players and guardians. Mol Cell 68:830-833.

Ray Chaudhuri A and Nussenzweig A (2017) The multifaceted roles of PARP1 in DNA repair and chromatin remodelling. Nat Rev Mol Cell Biol 18:610-621.

Ray Chaudhuri A, Hashimoto Y, Herrador R, Neelsen KJ, Fachinetti D, Bermejo R, Cocito A, Costanzo V and Lopes M (2012) Topoisomerase I poisoning results in PARP-mediated replication fork reversal. Nat Struct Mol Biol 19:417-423.

Robert I, Gaudot L, Rogier M, Heyer V, Noll A, Dantzer F and Reina-San-Martin B (2015) Parp3 negatively regulates immunoglobulin class switch recombination. PLoS Genet 11:e1005240.

Ronson GE, Piberger AL, Higgs MR, Olsen AL, Stewart GS, McHugh PJ, Petermann E and Lakin ND (2018) PARP1 and PARP2 stabilise replication forks at base excision repair intermediates through Fbh1-dependent Rad51 regulation. Nat Commun 9:746.

Rosenthal F and Hottiger MO (2014) Identification of ADPribosylated peptides and ADP-ribose acceptor sites. Front Biosci (Landmark Ed) 19:1041-1056.

Rulten SL, Fisher AE, Robert I, Zuma MC, Rouleau M, Ju L, Poirier G, Reina-San-Martin B and Caldecott KW (2011) PARP-3 and APLF function together to accelerate nonhomologous end-joining. Mol Cell 41:33-45.

Sakr Y, Elia C, Mascia L, Barberis B, Cardellino S, Livigni S, Fiore G, Filippini C and Ranieri VM (2013) The influence of gender on the epidemiology of and outcome from severe sepsis. Crit Care 17:R50.

Saleh-Gohari N, Bryant HE, Schultz N, Parker KM, Cassel TN and Helleday T (2005) Spontaneous homologous recombination is induced by collapsed replication forks that are caused by endogenous DNA single-strand breaks. Mol Cell Biol 25:7158-7169.

Satoh MS and Lindahl T (1992) Role of poly(ADP-ribose) formation in DNA repair. Nature 356:356-358.

Schmutz I, Timashev L, Xie W, Patel DJ and de Lange T (2017) TRF2 binds branched DNA to safeguard telomere integrity. Nat Struct Mol Biol 24:734-742.

Sevrioukova IF (2009) Redox-linked conformational dynamics in apoptosis-inducing factor. J Mol Biol 390:924-938.

Sfeir A and Symington LS (2015) Microhomology-mediated end joining: A back-up survival mechanism or dedicated pathway? Trends Biochem Sci 40:701-714.
Shahrour MA, Nicolae CM, Edvardson S, Ashhab M, Galvan AM, Constantin D, Abu-Libdeh B, Moldovan GL and Elpeleg O (2016) PARP10 deficiency manifests by severe developmental delay and DNA repair defect. Neurogenetics 17:227-232.

Sharifi R, Morra R, Appel CD, Tallis M, Chioza B, Jankevicius G, Simpson MA, Matic I, Ozkan E, Golia B et al. (2013) Deficiency of terminal ADP-ribose protein glycohydrolase TARG1/C6orf130 in neurodegenerative disease. EMBO J 32:1225-1237.

Sharma J, Nelluru G, Wilson MA, Johnston MV and Hossain MA (2011) Sex-specific activation of cell death signalling pathways in cerebellar granule neurons exposed to oxygen glucose deprivation followed by reoxygenation. ASN Neuro 3:e00056.

Shibata A, Jeggo P and Lobrich M (2018) The pendulum of the Ku-Ku clock. DNA Repair (Amst) 71:164-171.

Simon NC, Aktories K and Barbieri JT (2014) Novel bacterial ADP-ribosylating toxins: structure and function. Nat Rev Microbiol 12:599-611.

Smeenk G, Wiegant WW, Marteijn JA, Luijsterburg MS, Sroczynski N, Costelloe T, Romeijn RJ, Pastink A, Mailand N, Vermeulen W et al. (2013) Poly(ADP-ribosyl)ation links the chromatin remodeler SMARCA5/SNF2H to RNF168dependent DNA damage signaling. J Cell Sci 126:889-903.

Smith S, Giriat I, Schmitt A and de Lange T (1998) Tankyrase, a poly(ADP-ribose) polymerase at human telomeres. Science 282:1484-1487.

Szanto M, Brunyanszki A, Kiss B, Nagy L, Gergely P, Virag L and Bai P (2012) Poly(ADP-ribose) polymerase-2: emerging transcriptional roles of a DNA-repair protein. Cell Mol Life Sci 69:4079-4092.

Talhaoui I, Lebedeva NA, Zarkovic G, Saint-Pierre C, Kutuzov MM, Sukhanova MV, Matkarimov BT, Gasparutto D, Saparbaev MK, Lavrik OI et al. (2016) Poly(ADP-ribose) polymerases covalently modify strand break termini in DNA fragments in vitro. Nucleic Acids Res 44:9279-9295.

Tan B, Young DA, Lu ZH, Wang T, Meier TI, Shepard RL, Roth K, Zhai Y, Huss K, Kuo MS et al. (2013) Pharmacological inhibition of nicotinamide phosphoribosyltransferase (NAMPT), an enzyme essential for NAD+ biosynthesis, in human cancer cells: metabolic basis and potential clinical implications. J Biol Chem 288:3500-3511.

Tao Z, Gao P and Liu HW (2009) Identification of the ADPribosylation sites in the PARP-1 automodification domain: analysis and implications. J Am Chem Soc 131:1425814260.

Timinszky G, Till S, Hassa PO, Hothorn M, Kustatscher G, Nijmeijer B, Colombelli J, Altmeyer M, Stelzer EH, Scheffzek K et al. (2009) A macrodomain-containing histone rearranges chromatin upon sensing PARP1 activation. Nat Struct Mol Biol 16:923-929.

Tsurumura T, Tsumori Y, Qiu H, Oda M, Sakurai J, Nagahama M and Tsuge H (2013) Arginine ADP-ribosylation mechanism based on structural snapshots of iota-toxin and actin complex. Proc Natl Acad Sci U S A 110:4267-4272.

Tulin A and Spradling A (2003) Chromatin loosening by poly(ADP)-ribose polymerase (PARP) at Drosophila puff loci. Science 299:560-562.

Vagnerova K, Liu K, Ardeshiri A, Cheng J, Murphy SJ, Hurn PD and Herson PS (2010) Poly (ADP-ribose) polymerase-1 ini- 
tiated neuronal cell death pathway-do androgens matter? Neuroscience 166:476-481.

van Rijssel ER, van Delft P, Lodder G, Overkleeft HS, van der Marel GA, Filippov DV and Codee JD (2014) Furanosyl oxocarbenium ion stability and stereoselectivity. Angew Chem Int Ed Engl 53:10381-10385.

Verheugd P, Forst AH, Milke L, Herzog N, Feijs KL, Kremmer E, Kleine H and Luscher B (2013) Regulation of NF-kappaB signalling by the mono-ADP-ribosyltransferase ARTD10. Nat Commun 4:1683.

Virag L (2013) 50Years of poly(ADP-ribosyl)ation. Mol Aspects Med 34:1043-1045.

Vyas S, Matic I, Uchima L, Rood J, Zaja R, Hay RT, Ahel I and Chang P (2014) Family-wide analysis of poly(ADP-ribose) polymerase activity. Nat Commun 5:4426.

Wang Y, Kim NS, Li X, Greer PA, Koehler RC, Dawson VL and Dawson TM (2009) Calpain activation is not required for AIF translocation in PARP-1-dependent cell death (parthanatos). J Neurochem 110:687-696.

Wang Y, Kim NS, Haince JF, Kang HC, David KK, Andrabi SA, Poirier GG, Dawson VL and Dawson TM (2011) Poly(ADP-ribose) (PAR) binding to apoptosis-inducing factor is critical for PAR polymerase-1-dependent cell death (parthanatos). Sci Signal 4:ra20.

Wang Y, An R, Umanah GK, Park H, Nambiar K, Eacker SM, Kim B, Bao L, Harraz MM, Chang C et al. (2016a) A nuclease that mediates cell death induced by DNA damage and poly(ADP-ribose) polymerase-1. Science 354:aad6872.

Wang YQ, Wang PY, Wang YT, Yang GF, Zhang A and Miao ZH (2016b) An Update on Poly(ADP-ribose)polymerase-1 (PARP-1) Opportunities and challenges in cancer therapy. J Med Chem 59:9575-9598.

Welsby I, Hutin D, Gueydan C, Kruys V, Rongvaux A and Leo O (2014) PARP12, an interferon-stimulated gene involved in the control of protein translation and inflammation. J Biol Chem 289:26642-26657.

Wertz IE and Wang X (2019) From discovery to bedside: Targeting the ubiquitin system. Cell Chem Biol 26:156-177.

Wright RH, Lioutas A, Le Dily F, Soronellas D, Pohl A, Bonet J, Nacht AS, Samino S, Font-Mateu J, Vicent GP et al. (2016) ADP-ribose-derived nuclear ATP synthesis by NUDIX5 is required for chromatin remodeling. Science 352:1221-1225.

Yan Q, Xu R, Zhu L, Cheng X, Wang Z, Manis J and Shipp MA (2013) BAL1 and its partner E3 ligase, BBAP, link
Poly(ADP-ribose) activation, ubiquitylation, and doublestrand DNA repair independent of ATM, MDC1, and RNF8. Mol Cell Biol 33:845-857.

Yang G, Liu C, Chen SH, Kassab MA, Hoff JD, Walter NG and Yu X (2018) Super-resolution imaging identifies PARP1 and the Ku complex acting as DNA double-strand break sensors. Nucleic Acids Res 46:3446-3457.

Yoneyama-Hirozane M, Matsumoto SI, Toyoda Y, Saikatendu KS, Zama Y, Yonemori K, Oonishi M, Ishii T and Kawamoto T (2017) Identification of PARP14 inhibitors using novel methods for detecting auto-ribosylation. Biochem Biophys Res Commun 486:626-631.

Yu SW, Wang H, Poitras MF, Coombs C, Bowers WJ, Federoff HJ, Poirier GG, Dawson TM and Dawson VL (2002) Mediation of poly(ADP-ribose) polymerase-1-dependent cell death by apoptosis-inducing factor. Science 297:259-263.

Yuan M, Siegel C, Zeng Z, Li J, Liu F and McCullough LD (2009) Sex differences in the response to activation of the poly (ADP-ribose) polymerase pathway after experimental stroke. Exp Neurol 217:210-218.

Zarkovic G, Belousova EA, Talhaoui I, Saint-Pierre C, Kutuzov MM, Matkarimov BT, Biard D, Gasparutto D, Lavrik OI and Ishchenko AA (2018) Characterization of DNA ADPribosyltransferase activities of PARP2 and PARP3: new insights into DNA ADP-ribosylation. Nucleic Acids Res 46:2417-2431.

Zellweger R, Dalcher D, Mutreja K, Berti M, Schmid JA, Herrador R, Vindigni A and Lopes M (2015) Rad51-mediated replication fork reversal is a global response to genotoxic treatments in human cells. J Cell Biol 208:563-579.

Zhang J, Liu D, Zhang M and Zhang Y (2018) Programmed necrosis in cardiomyocytes: mitochondria, death receptors and beyond. Br J Pharmacol.

Zhang Y, Mao D, Roswit WT, Jin X, Patel AC, Patel DA, Agapov E, Wang Z, Tidwell RM, Atkinson JJ et al. (2015) PARP9DTX3L ubiquitin ligase targets host histone H2BJ and viral $3 \mathrm{C}$ protease to enhance interferon signaling and control viral infection. Nat Immunol 16:1215-1227.

Associate Editor: Carlos F. M. Menck

License information: This is an open-access article distributed under the terms of the Creative Commons Attribution License (type CC-BY), which permits unrestricted use, distribution and reproduction in any medium, provided the original article is properly cited. 